\title{
"Sejamos brasileiros no dia da nossa nacionalidade": comemoraçōes da Independência no Rio de Janeiro, 1840-1864
}

Hendrik Kraay

Antes do amanhecer de 7 de setembro de 1853, José Maria do Amaral "e alguns brasileiros distintos" subiram ao pico do Corcovado e, quando o sol raiava, fundaram a Sociedade dos Cavaleiros do Ipiranga. ${ }^{1}$ Os objetivos da sociedade eram comemorar a Independência do Brasil a cada 7 de setembro, construir "um monumento grandioso" em honra da Independência, "desenvolver e sustentar a nacionalidade" e coletar documentos e objetos ligados à "declaração da Independência". ${ }^{2}$ Esta sociedade patriótica foi criada oficialmente em 1855 como a Sociedade Ipiranga; a sua primeira diretoria definiu-a como uma sociedade "cujo fim patriótico e filantrópico não se limita aos pueris folguedos de um povo sem idéias, mas a perpetuar cada ano com um ato significativo o aniversário da Independência do Império". Em 1856 a sociedade contava com quase 900 membros, cada um dos quais pagara uma cota de seis mil réis. ${ }^{3}$

Durante alguns anos a sociedade esteve à frente de mudanças importantes nas comemorações da Independência do Brasil na capital do Rio de Janeiro, que as transformaram em festejos de rua de monta. Outras sociedades análogas se juntaram à Ipiranga na promoção de comemoraçôes. A dimensão destas manifestações patrióticas surpreendeu os contemporâneos e levanta questôes relevantes a respeito da natureza do envolvimento dos brasileiros do século XIX com o Estado imperial, do alcance social da nação brasileira construído através destes rituais e do conteúdo da identidade brasileira expresso publicamente nas ruas e praças da capital.

As celebrações do 7 de Setembro aludiam ao dia, em 1822, quando Pedro, filho do rei de Portugal, anunciou publicamente sua ruptura com o governo em Lisboa. Às margens do rio Ipiranga, em São Paulo, respondeu a cartas vindas de Lisboa com a declaração "Independência ou Morte", um evento posteriormente interpretado como a proclamação da Inde- 
pendência e o momento de fundação da nação brasileira. Em 1822, todavia, pouca gente deu maior atenção a este episódio, embora, no ano seguinte, a fadada ao fracasso Assembléia Constituinte decidisse que o 7 de Setembro deveria ser o "aniversário da Independência”. Em 1826 foi incluído nos feriados imperiais nacionais e no final dessa década estava claramente entronado como o mais importante "dia de festividade nacional" na capital. ${ }^{4}$ Como para todos os símbolos bem sucedidos, a força do 7 de Setembro residia na sua natureza polivalente. Por um lado, oferecia uma origem monárquica adequada para o Império, celebrando atos de um príncipe que proclamou a Independência e que, em 1824, outorgou uma constituição. Por outro lado, isto a partir do final da década de 1820, os exaltados podiam interpretar as atitudes de Pedro I como resposta a demandas populares por um rompimento com Portugal. Nesta perspectiva, o monarca era apenas o servidor da nação brasileira e o 7 de Setembro celebrava o papel do povo. ${ }^{5}$

Rituais cívicos fornecem uma perspectiva extremamente rica sobre os processos complexos de constituiçãa do Estado - e da nação - bem como sobre a formação de identidades coletivas. São simultaneamente "ritos de poder", liturgias através das quais as autoridades exprimem e atualizam sua pretensão a domínio legítimo e, potencialmente, espaços onde oponentes da ordem prevalecente tornam suas demandas públicas. ${ }^{6}$ Nos países latino-americanos recém independentes, os rituais cívicos eram ferramentas importantes para as elites que buscavam criar novas naçōes. ${ }^{7}$ Todavia, os rituais cívicos também colocam dificuldades de interpretação delicadas. Como Claudio Lomnitz-Adler aponta, "rituais e mitos nacionais de fato revelam princípios gerais que operam na sociedade política mas não mostram com facilidade os modos como estes princípios articulam as várias classes sociais e os grupos dentro da nação". Noutros termos, permanece algo difícil avaliar a "efetividade" dos rituais cívicos na construção de nações ou na promoção de lealdade para com o Estado. ${ }^{8}$ Não obstante, um acompanhamento detalhado, tanto das práticas das celebrações do 7 de Setembro como, mais importante, dos discursos que as rodearam, pode revelar muito sobre a compreensão dos brasileiros a respeito da sua identidade coletiva como membros da nação. 
Este artigo atém-se ao Rio de Janeiro durante um período relativamente curto, da década de 1840 ao início da década de 1860. A capital do Império brasileiro era então uma grande metrópole comercial, com uma população de 206.000 pessoas, conforme um censo de 1849 ; dois terços dos 79.000 escravos que trabalhavam na cidade eram africanos. ${ }^{9}$ Uma hierarquia racial complexa, na sua maior parte não sancionada legalmente, estruturava as relações entre os que eram livres. Como sede do governo e da monarquia brasileiros, o Rio de Janeiro tinha forte presença estatal por comparação com o resto do Brasil. Em 1840, Pedro II, então com 14 anos, ascendeu ao poder; a maior parte desta década foi dominada por campanhas contra rebeliōes regionais no vasto Império. $\mathrm{O}$ último destes movimentos foi derrotado em 1849 e os pacíficos anos da década de 1850 e do início da de 1860 são normalmente encarados como correspondendo ao apogeu do regime imperial, uma época em que prevaleceu uma aceitação generalizada das instituições políticas imperiais. ${ }^{10}$

$\mathrm{Na}$ década de 1840 e início da década de 1850, as celebrações do 7 de Setembro tinham se tornado rotineiras, organizadas pelo Estado, com pouquíssimo espaço para participação do populacho ou da sociedade civil. Apenas fracos ecos dos debates iniciais sobre o sentido do 7 de Setembro ainda podiam ser ouvidos. A Sociedade Ipiranga e mais cerca de uma dúzia de sociedades análogas criadas em meados da década de 1850 transformaram o feriado num festival de rua que durava três dias e que envolvia uma parcela significativa da população da capital. Embora de curta duração, este período de celebraçôes intensas do 7 de Setembro oferece um material vasto para analisar a concepção da nação brasileira expressa publicamente nas ruas da cidade e em espaços mais restritos de comemoração como os teatros. Nas manifestações rituais públicas, a nação brasileira era "civilizada", suas instituiçõos públicas superiores garantiam o progresso ordeiro do país. A nação albergava um espectro relativamente amplo da população urbana, muito embora as celebrações definissem fronteiras claras entre brasileiros e os que estavam excluídos da nação - africanos, vadios, índios e escravos (apesar destes últimos, se nascidos no Brasil, poderem ser incorporados numa posição subordinada). 
$\mathrm{Na}$ forma do costume: comemorações na década de 1840 e início da década de 1850

$\mathrm{Na}$ década de 1840, havia uma rotina para os principais rituais cívicos e os jornais noticiavam que as celebrações do 7 de Setembro haviam ocorrido "na forma do costume". A cidade despertava com salvas de artilharia disparadas de suas fortalezas e dos navios de guerra que se repetiam ao meio-dia e ao anoitecer. Em 1842, o Príncipe da Prússia Adalberto esteve em companhia do jovem Imperador Pedro II durante todo o dia e proveu uma descrição detalhada das celebraçōes oficiais. Ele observou a Guarda Nacional, nos seus uniformes verdes e amarelos, formar no "um tanto desolado" Campo de Santana. Nesse dia, Pedro lançou a pedra fundamental de um orfanato, após o que Adalberto o acompanhou no cortejo até a cidade, a partir do paço de São Cristóvão. As ruas estavam "cheias de gente; em todas as esquinas juntavam-se grupos de escravos negros, para saudar o imperador; viam-se agrupadas gentes de todos os tons, do negro e mulato ao mestiço e ao janota branco". Após a missa de Te Deum na capela imperial, Pedro passou as tropas em revista a partir da sacada do paço da cidade (na atual Praça XV); as tropas desfilavam em parada e disparavam salvas. A isto seguiu-se um cortejo, durante o qual "as autoridades militares e civis... marchavam em diversos corpos para beijar a mão do imperador, o assim chamado beija-mão". As celebrações oficiais encerraram-se com um teatro de gala ao qual Adalberto também esteve presente (vide abaixo). ${ }^{11}$

Nos anos iniciais da década de 1850, as celebrações do 7 de Setembro mantiveram este padrão. Grande parada, Te Deum, desfile militar, cortejo e beija-mão repetiam-se ano após ano (exceto quando houve chuvas torrenciais, como em 1850 e 1855, ou quando o governo cancelou a parada por causa de eleiçóes), do mesmo modo que as salvas de artilharia ao amanhecer, ao meio-dia e ao anoitecer. Em tais ritos de poder praticamente não havia lugar para a maioria da população da cidade, reduzida ao papel de espectadora. Os cidadãos - homens com rendimento acima de 200 mil-réis - eram cuidadosamente arregimentados na Guarda Nacional. O monarca tinha um papel central em todas as cerimônias e a elite da cidade prestava-lhe obediência formal durante o cortejo; o monarca também a 
recebia, de modo menos formal, das multidóes que o saudavam quando entrava na cidade. Vários aspectos deste ritual derivavam de práticas do antigo regime, embora seja surpreendente que muitos poucos historiadores tenham estabelecido conexóes entre os rituais monárquicos coloniais e os do Império independente. ${ }^{12}$

Pelo menos tão importante quanto a prática ritual em si é o discurso a respeito. Alentadas crônicas jornalísticas explicavam o significado do 7 de Setembro, desta forma dando sentido ao ritual, bem como contribuindo para a criação de uma "comunidade imaginada" de brasileiros. ${ }^{13} \mathrm{De}$ meados da década de 1840 ao início da década de 1850 , houve relativamente pouca controvérsia na imprensa sobre o significado do 7 de Setembro. Os jornais podiam dar maior ou menor ênfase às ações de Pedro I, mas raramente questionavam seu papel. Repetidamente proclamavam que o 7 de Setembro celebrava tanto a Independência quanto a Constituição. Fora o dia, explicava um jornal, no qual um "príncipe magnânimo (...) inaugurou uma vida de independência e liberdade" ${ }^{14}$ A Independência era, de acordo com outro jornal, a "obra magnífica de um príncipe verdadeiramente liberal, secundado em seus heróicos esforços pelo patriotismo e luzes de muitos distintos brasileiros". ${ }^{15} \mathrm{O}$ sucesso do Brasil em evitar a anarquia e a revolução durante a monarquia constitucional era exemplo para seus desafortunados vizinhos republicanos, exultava um terceiro jornal em $1854 .{ }^{16}$ Nesse ano, a campanha para erigir um monumento a Pedro I como fundador do Império, que definhara desde a década de 1820, finalmente voltou à tona e resultaria, oito anos mais tarde, na inauguração da estátua eqüestre na Praça da Constituição (hoje Praça Tiradentes). A concepção do monumento - Pedro I a cavalo segurando a Constituição refletia a visão dominante do primeiro imperador como proclamador da Independência e como doador da Constituição. ${ }^{17}$

Um segundo tópico nas discussões sobre o significado do 7 de Setembro era a relevância do progresso. Em 1845, pouco após as negociações que puseram cobro à Rebelião Farroupilha que há muito se arrastava no Rio Grande do Sul, O Mercantil proclamou que o Brasil, sob sua monarquia constitucional, agora "caminha na estrada de progresso à pacífica conquista das artes, da civilização e da prosperidade moral e material". ${ }^{18} \mathrm{~A}$ inauguração do novo encanamento do Maracanã em 1851 foi ocasião que 
propiciou uma retórica congratulatória sobre o progresso do Brasil: nem mesmo Londres, elucidava um cronista, tinha um sistema de águas urbano tão sofisticado. ${ }^{19}$ Outros podiam lamentar que o Brasil não tivesse progredido suficientemente. Em 1843, O Echo do Rio declarou que o Brasil ainda estava "mui longe de onde devia estar" e, dois anos após a sua avaliação otimista das perspectivas para o Brasil, O Mercantil lamentava a falta de progresso material e conclamava os brasileiros a unirem-se para elevar seu país ao nível das "cultas nações da Europa". ${ }^{20}$

Desde a década de 1820, os exaltados haviam tendido a minimizar o papel de Pedro I na obtenção da Independência; ao invés, destacavam as origens populares da Independência e argumentavam que o monarca meramente acompanhara a liderança popular (e que, na verdade, a pressão popular o obrigara a outorgar a Constituição). O Mercantil expressava esta concepção em tom moderado em 1845, quando considerava que em 1822 "anuiu o príncipe aos ardentes desejos dos brasileiros". ${ }^{21}$ No seu auge no início da década de 1830, os exaltados haviam criado elaboradas celebraçôes do 7 de Setembro que em boa parte ignoravam o monarca. Tinham encontrado no nativismo antiportuguês um instrumento poderoso de mobilização popular - o comerciante português que enganava nas contas era um dos alvos favoritos do opróbrio das classes baixas - e, para os exaltados, o envolvimento popular nas celebraçôes do 7 de Setembro demonstrava verdadeiro patriotismo. ${ }^{22}$

Em 1848, os exaltados foram para as ruas no 7 de Setembro durante eleições municipais fortemente disputadas. Segundo jornais conservadores, essas demonstrações foram pouco mais do que "gritos sinistros de vivas e morras! que soltava um magote de poviléu aluminado por archotes". Aparentemente a manifestação havia sido planejada antes, já que os que protestavam eram acompanhados por bandas de música enquanto desfilavam pelas freguesias do centro da cidade. No dia seguinte, transformou-se em ataques patrióticos nativistas isolados a portugueses, os quais rapidamente foram interrompidos pela polícia. O liberal moderado Correio Mercantil defendeu que a multidão apenas deu vivas "aos objetos de nossos cultos" no 7 de Setembro, condenou os "gritos imprudentes" isolados e negou que a agitação antiportuguesa fosse justificada. Alguns dias depois, este jornal lamentava que o governo houvesse invocado uma lei que proi- 
bia ajuntamentos ilícitos por forma a "dispersar os que festejavam com vivas e música o dia 7 de Setembro", uma opinião que jornais exaltados de efêmera duração expressaram com muito mais vigor do que o Correio. ${ }^{23}$

Em jogo no 7 de Setembro de 1848 estava o papel do "povo" - uma categoria vagamente definida - na nação brasileira. Para jornais conservadores, era perigoso demais ter grupos de pessoas sem freio, mesmo que patrióticos, nas ruas nos feriados nacionais, já que poderiam obter controle das expressões simbólicas da nação; sem falar em perpetrarem ações violentas. Dois pilares do jornalismo político do Rio de Janeiro voltaram a debater o assunto em 1854. Antônio Borges da Fonseca, um antigo exaltado, lamentou que o 7 de Setembro passara "sem recordação nem entusiasmo", ao que o conservador Justiniano José da Rocha retorquiu que Borges da Fonseca só percebia como verdadeiros festivais nacionais aqueles onde "correm em turba multa pelas ruas bandos populares soltando, entre vivas, vociferações de morte". O Brasil tinha presenciado um festival desse tipo pela última vez em 1848, mas agora a nação percebia a necessidade de paz e progresso. Hoje em dia ninguém acredita na "insídia revolucionária" que levara a juventude a crer que "planos absurdos de colonização estavam traçados" de modo que não havia mais pretextos nem justificativas para "estrepitosas demonstraçôes". ${ }^{24}$ Borges da Fonseca respondeu que, na verdade, o Brasil ainda não estava livre dos portugueses e destacou que os Estados Unidos celebravam a sua Independência entusiasticamente, como faziam os baianos no 2 de julho. No Rio de Janeiro, "nem uma luminária se botou, porque esta cidade é dos portugueses". ${ }^{25}$

Fogo de Palha? Celebrações nas décadas de 1850 e 1860

Passados um ou dois anos da lamentação de Borges da Fonseca, as celebraçóes do 7 de Setembro na capital mostraram um reavivamento notável. Na liderança estava a Sociedade Ipiranga, acompanhada por ao menos uma dúzia de outras sociedades, que se encarregaram da tarefa de rejuvenescer as formas tradicionais de comemoração e instituíram novas tradições. Em 1855 e nos anos seguintes, a Sociedade Ipiranga pedia que os moradores mais uma vez iluminassem as janelas de suas casas em honra da Independência, o costume colonial tradicional cujo desaparecimento 
Borges da Fonseca lamentara. ${ }^{26}$ Em 1856 e 1857, a Sociedade preparou programas detalhados para as celebrações. Ao raiar do 7 de Setembro, uma banda de música tocaria o hino da Independência na Praça da Constituição, o local que fora designado para a estátua eqüestre de Pedro I. Na mesma hora, fogos de artifício espocados nos morros da cidade anunciariam o começo das festividades, junto com salvas de artilharia a partir das fortalezas e dos navios no porto. Isto se repetiria à uma da tarde e ao anoitecer. Uma delegação da sociedade fora designada para auxiliar o cortejo e, às quatro da tarde, a sociedade mandaria cantar um Te Deum na capela da Ordem Terceira do Carmo. Após, todos os membros da sociedade desfilariam para as dependências da Câmara Municipal para aí prestar homenagem ao retrato de Pedro I. A sociedade contratou bandas de música para tocar na frente do prédio da Câmara e, em 1865, planejou um espetáculo de fogos de artifício para depois da gala teatral. No ano seguinte, programou fogos de artifício para 9 de setembro. ${ }^{27}$ Outras sociedades fizeram coisas parecidas. A Sociedade Independência Brasileira reivindicou o Largo de São Domingos (desaparecido em 1943 com a construção da Avenida Presidente Vargas) como local para o seu festival e ergueu monumentos temporários (iluminaçôes) em 1857 e 1858, quando já o chamava de celebração costumeira. ${ }^{28}$

Todos os relatos de jornais da segunda metade da década de 1850 concordam com que os esforços destas sociedades haviam transformado o 7 de Setembro. Embora um cronista do Jornal do Commercio avaliasse o evento de 1855 como "frio, friíssimo", no ano seguinte mal podia se conter na descrição do "ruído de alegria", encabeçado pela Sociedade Artista Nacional e pela Sociedade Ipiranga. A sociedade dos artesãos ergueu um arco triunfal no Largo do Paço (atual Praça XV), enquanto que a Sociedade Ipiranga celebrava na Praça da Constituição. Vários prédios públicos e privados eram iluminados. O ritual oficial costumeiro ocorreu, à exceção da tradicional parada da Guarda Nacional, mas todos os olhares estavam voltados para o que os jornais chamavam os "festejos populares". ${ }^{29} \mathrm{Em}$ 1857, descrevia o cronista de um jornal, o Rio de Janeiro desfrutou de "três noites de iluminação, salvas, girândolas e foguetes a mais não poder, músicas em coretos e pelas ruas, jantares e reuniōes patrióticas, e, enfim, um fogo de artifício queimado em frente ao paço municipal, onde se acha- 
vam SS. MM. Imperiais”. ${ }^{30}$ Em 1858, toda a família real percorreu a pé vários dos monumentos e os festivais de rua. ${ }^{31}$ As celebraçôes começaram ainda mais cedo em 1859. À meia-noite, centenas de girândolas iluminaram o céu; "milhares de cidadãos de todas as classes e posiçôes" se levantaram bem antes do nascer-do-sol "para saudarem o alvorecer do primeiro dia nacional". Na Praça da Constituição, uma sociedade erguera uma fonte, encimada por um busto de Pedro I e sustentada pelos quatro grandes rios do Brasil (o Prata, o Amazonas, o Tocantins e o São Francisco), cercada por vinte pilares com estrelas representando as províncias. Outras sociedades também ergueram estruturas alegóricas efêmeras. Bandas de música e delegações de sociedades patrióticas circulavam pelas ruas, visitando os festejos umas das outras e atraindo multidões. ${ }^{32}$

Ao mesmo tempo, comissões de bairro começaram a arrecadar fundos e a organizar celebrações de 7 de Setembro. Em 1858 e 1859, moradores de vários bairros pediram permissão à Câmara Municipal para erguer monumentos e plataformas de fogos de artifício nas ruas da cidade; outros montaram coretos para bandas e organizaram programaçóes musicais. ${ }^{33}$ Por vezes emergiam críticas aos esforços das comissões de bairro; em 1857, "O Oprimido" reclamava que muitas destas subscrições eram organizadas por vereadores e outros funcionários que, escorados num destacamento de guardas municipais, intimidavam os moradores a contribuir para as celebrações. ${ }^{34}$ Já outros se preocupavam com que a proliferação de festejos estaria diluindo as comemorações, enquanto que um jornal satírico anunciava - ironicamente - em 1859 que um arco triunfal seria erguido entre as fortalezas de Santa Cruz e São João, localizadas nos lados opostos da entrada da baía! 35

O discurso dominante destas celebrações negava divisões entre os brasileiros. O autor de uma proclamação de 7 de Setembro conclamava compatriotas a que "sejamos brasileiros no dia da nossa nacionalidade" e um cronista do Jornal do Commercio comentava que era "o dia da recordação do mais belo feito, dia em que desaparecem todas as divisões de partidos (...), dia em que todos são verdadeiramente irmãos pela pátria" ${ }^{36}$ Vários pequenos e efêmeros jornais de oposição repetiam ao longo destes anos temas exaltados familiares, sobre despotismo do governo e nativismo antiportuguês, mas aparentemente sem impacto sobre as celebrações. Em 
1857, O Tirano denunciou a violência sofrida por homens da Guarda Nacional perpetrada por seus oficiais, queixou-se que a polícia prendeu pessoas indiscriminadamente "nos três dias de solenidade à liberdade" e lamentou a sina "dos pobres cidadãos, escravos do despotismo [do governo]", encarcerados no Presiganga, ele próprio decorado em honra da Independência brasileira. Condenações ao controle estrangeiro (português) do Comercio e à falta de voto livre estavam também envolvidas no patriotismo do 7 de Setembro. ${ }^{37}$

Sem razão aparente, esta explosão de comemorações patrióticas declinou de modo quase tão abrupto como irrompera. As celebrações de 1860 foram "menos brilhantes" do que as dos anos anteriores, mas o cronista do Jornal do Commercio consolava-se com a forma pacífica das eleições desse dia, prova do progresso ordeiro do país. ${ }^{38} \mathrm{Em}$ 1861, a Revista Popular declarava que "triste, desanimado desceu ao abismo do passado o primeiro dia brasileiro". Aqueles que, apenas alguns anos antes, haviam duvidado da durabilidade da "labareda falaz de improvisado patriotismo" estavam certos ao qualificá-la de mero "fogo de palha". ${ }^{39}$ No ano seguinte, as coisas pouco tinham melhorado. Um jornal criticou a Sociedade Ipiranga por praticamente nada fazer além de erguer dois coretos ao lado da recéminaugurada estátua eqüestre e apressadamente os desmontar no dia seguinte. Mais caridosamente, outro jornal relatou que uns poucos radicais desta sociedade e da Sociedade Festival Sete de Setembro se levantaram cedo para saudar a estátua ao amanhecer. Até mesmo o Imperador se admirou d'"a frieza com que este ano se festejou este dia atento o entusiasmo de há poucos anos". O Espectador da América do Sul concordava com esta avaliação em 1863: "Já não temos aquelas festas populares, chamadas da Independência, em que, outrora, o povo, todo coração, rememorava, quase com ternura, o aniversário natalício da mãe comum." Nesse ano, a Sociedade Ipiranga parou de cobrar anuidades e anunciou que não promoveria quaisquer comemoraçôes. ${ }^{40}$

Refazendo ruas e sociedade: imaginando o Brasil, 1856-1859

O repentino afluir e desaparecer destas comemorações do 7 de Setembro é tão inexplicável hoje quanto era para os contemporâneos. É níti- 
do que tais celebrações diferiam em vários aspectos significativos das demonstrações dos exaltados de 1848; havia participação popular mas não se tratava de um desafio ao governo. Uma análise mais de perto das celebrações do final da década de 1850 aponta para traços-chave do Brasil imaginado pelos organizadores do festival os quais, como os jornais sugerem de modo implícito, mereceram aprovação popular, demonstrada através da participação nas celebrações.

Praticamente nada se sabe sobre os líderes ou sobre os membros comuns das sociedades que lideravam as celebraçôes no final da década de 1850. Não consegui encontrar listagens de afiliados e apenas obtive indicações esparsas de quem eram seus diretores. A julgar pelo nome, a Sociedade Artista Nacional incluía homens dessa camada da população (artesãos); as anuidades recolhidas dos membros pela Sociedade Ipiranga, embora relativamente modestas, excluiriam a maioria da população da cidade. Figuras proeminentes desta sociedade incluíam Manoel de Araújo Porto Alegre, diretor da Academia Imperial de Belas Artes, figura de proa da elite cultural da cidade e protegido de Pedro II; por várias vezes foi o orador oficial da sociedade. Antônio Borges da Fonseca também apoiava a sociedade, através da impressão de graça de seus estatutos. ${ }^{41}$

Indicações adicionais sobre as camadas atraídas por estas celebraçōes - e portanto sobre os limites da nação nelas imaginada - podem ser encontradas na cobertura jornalística do 7 de Setembro. Mais do que tudo, a imprensa destacava que as celebrações eram ordeiras e pacíficas. Praticamente não se passava um ano sem que os jornais comentassem que as multidóes se haviam comportado de modo ordeiro, uma indicação indireta da preocupação com que grandes ajuntamentos podiam ser encarados. Para além disso, não havia manifestações das "teorias perigosas de uma liberdade mal-entendida", tais como as de $1848 .{ }^{42}$

A noção de respeitabilidade tinha relação muito próxima com a de ordem. Celebrações de rua noturnas implicavam uma grande alteração desse espaço público, normalmente não considerado seguro nem apropriado para os "honrados" membros das classes média e alta da sociedade. ${ }^{43}$ Os que viviam e trabalhavam nas ruas também constituiam obstáculos. As quitandeiras (provavelmente africanas) do Largo do Capim (desaparecido em 1943 com a construção da Avenidade Presidente Vargas) 
tiveram que sair em 1858 para dar espaço para que se erguesse um arco triunfal e um jornal dizia esperar que o governo tornasse tal remoção permanente. ${ }^{44}$ A iluminação tinha papel proeminente nesta transformação do espaço público. As iluminações, tanto os monumentos temporários como a prática de acender velas e lanternas nas janelas da frente das casas, tornou possível aos senhores e senhoras freqüentarem as celebrações. $\mathrm{O}$ seu impacto numa época de iluminação inadequada das ruas era muito maior do que hoje se suporia. Na semana antes do 7 de Setembro, as lojas tinham animadas vendas de uma luxuriante variedade de lâmpadas cuidadosamente descrita em anúncios detalhados nos jornais. A loja de Manoel Olegário Abranches era líder como "inovador de bom gosto" para substituir a "tristonha lamparina" com "uma iluminação elegante" como a que se usava em Paris. ${ }^{45}$ Relatos de demonstraçōes experimentais de iluminação elétrica apontam para um fascínio pelas novas tecnologias que podiam transformar a noite em dia. ${ }^{46}$

Todavia, apenas formas novas e modernas de iluminação eram aceitáveis. Planos de fazer grandes fogueiras nos morros em torno da cidade resultaram numa vigorosa condenação em 1856 . O autor de uma carta ao redator condenava este "tresloucado projeto", já que o 7 de Setembro nunca deveria ser celebrado, concluía ele, "com fogueiras à maneira de selvagens ou gente da roça”. ${ }^{47}$ Não é pois surpreendente que nunca mais tenham sido acesas fogueiras neste período. Outros tipos de celebração que desmentiam a imagem de civilização sendo construída tão a custo na capital também eram mal recebidos. Em 1845, o Jornal do Commercio queixava-se dos capoeiras que se juntavam às multidôes e aterrorizavam cidadãos respeitáveis, mas não havia repressão policial que desse cobro a esta prática. Há registro de prisões ocasionais de capoeiristas durante as celebrações. ${ }^{48}$ Subjacente a estas preocupações estava o desejo fervente de que "os estrangeiros que partilharem do nosso entusiasmo não tenham que censurar dos nossos conhecimentos, civilização e progresso" ${ }^{49}$

A transformação do espaço público era, contudo, apenas temporária e, durante o período liminar do início da manhã, quando as celebrações arrefeciam, as ruas voltavam à sua condição anterior. Foliōes respeitáveis que deixavam de voltar para casa a tempo corriam riscos. Em 1857, um grupo de caixeiros insultou uma mulher enquanto voltava para casa com seu marido. ${ }^{50} \mathrm{Um}$ incidente mais sério aconteceu em 1859 , quando a polí- 
cia prendeu um espanhol que proferira "gracejos ofensivos" e insultara "senhoras" que estavam saindo das celebrações na Praça da Constituição. Ele ofendera uma "mulher" com uma "ação indecente"; antes que o acompanhante dela pudesse reagir, a polícia prendeu o espanhol. Uma multidão de cerca de duzentas pessoas se juntou, algumas gritando para que o homem fosse solto, outras saudando as ações da polícia. À medida que a multidão se dispersava, um grupo passou a vandalizar a fonte, já sem iluminação, que fora erguida para as celebrações, entre gritos de "morra o chefe de polícia". Membros da sociedade que erguera o monumento desfrutavam de um jantar tardio numa casa próxima e acorreram a proteger a obra. Tentaram em vão acalmar o populacho explicando que era errado destruir "uma obra levantada em aplauso da Independência da pátria". Finalmente a cavalaria policial chegou e prendeu vinte e cinco homens: "treze brasileiros de condição inferior", dez caixeiros portugueses desempregados, um francês e um escravo. O Jornal do Commercio negou que o ato de vandalismo tivesse qualquer significado político, explicando que fora perpetrado por "vadios e turbulentos, desses que abundam em todas as cidades para dar que fazer à polícia". Outro jornal condenou o uso excessivo de força pela polícia contra a população. ${ }^{51}$

Como o Jornal do Commercio deixava claro, a nação brasileira necessariamente excluía muitos, que precisavam ser controlados pela polícia. $\mathrm{O}$ tema da escravidão também levantava questões sobre o Brasil imaginado pelos foliōes do 7 de Setembro. Em 1857, os fundadores da Sociedade Ipiranga declararam que um dos objetivos da sociedade era promover o "amor da liberdade, e o ódio da escravidão". $\mathrm{Na}$ época, não havia nenhum movimento ativo abolicionista no Brasil, embora subvençôes britânicas tivessem viabilizado a publicação de jornais abolicionistas e algumas pequenas sociedades abolicionistas houvessem existido no início da década. ${ }^{52}$ A notícia de que a sociedade planejava libertar escravos no 7 de Setembro de 1856 provocou um tumulto na cidade. Boatos se espalharam entre as "classes ínfimas" de que todos os escravos seriam libertos nesse dia. ${ }^{53}$ Sem se abalar, a sociedade sorteou cinco do "grande número de escravas" cujos nomes haviam sido propostos pelos afiliados e das quais os donos se dispunham a abrir mão sem grandes exigências. Eram só mulheres, algo que a sociedade estipulara, e três eram identificadas como pardas; 
sob estes aspectos eram típicas dos escravos que ganhavam alforria. ${ }^{54}$ Dúbio a respeito dos procedimentos, o cronista do Correio da Tarde externava sua preocupação com que, sem um apoio continuado, as mulheres cairiam na prostituição. ${ }^{55} \mathrm{O}$ seu correlato do Correio Mercantil, todavia, apoiava irrestritamente as alforrias, pois os recém-libertos para sempre associariam "o maior dia de sua vida ao maior dia da história de um povo". ${ }^{56}$

Apesar das controvérsias de 1856, no ano seguinte a Sociedade Ipiranga e as comissões paroquiais que organizava conseguiram levantar fundos suficientes para libertar vinte e dois escravos que, como exultava o cronista do Jornal do Commercio, "entravam assim no grande grêmio dessa nação para quem o dogma filosófico e cristão da fraternidade e da igualdade humana não é uma teoria contestada por orgulhoso preconceito". ${ }^{57}$ A Sociedade Independência Nacional foi criada nesse ano com o objetivo expresso de libertar escravos (e promover "festejos populares") no 7 de Setembro. ${ }^{58}$ Apesar do entusiasmo de 1857 , no ano seguinte, não houve mais alforrias patrióticas; elas só se tornariam um traço importante dos rituais cívicos na década de 1880, quando o movimento abolicionista ressurgente percebeu que o fim da escravidão estava próximo. Na verdade, nenhuma sociedade libertou escravos em 1858 ou nos três anos seguintes (e apenas um jornal comentou o fato). A última alforria de 7 de Setembro ocorreu em 1862, quando a endividada Sociedade Conservadora Sete de Setembro viu-se sem fundos suficientes para erguer uma celebração pública e optou por utilizar o dinheiro que lhe restava na libertação de um menino escravo. ${ }^{59}$ Em suma, libertar escravos era uma ação demasiado perigosa num período em que a escravidão ainda florescia.

Civilização, respeitabilidade, inquietação com as percepções dos estrangeiros, preocupaçóes com excluir qualquer coisa que lembrasse o Brasil africano ou índio e dúvidas a respeito de alforria, tudo sugere que as amplas celebrações de 1856-59 permaneceram firmemente sob controle da elite brasileira. É bem verdade que havia uma certa participação popular, mas a retórica da nacionalidade excluía africanos e índios e qualquer coisa que não alcançasse os padrões de uma civilização idealizada. Apenas multidões ordeiras, apolíticas, eram bem vindas às comemorações; na melhor das hipóteses, as pessoas do povo podiam ser membros subordinados da nação. Um olhar mais de perto para as ações das classes média e alta 
no 7 de Setembro fornece uma outra via para lidar com esta questão do que as celebrações significavam para os com elas envolvidos.

De casa para o teatro: a sociabilidade das classes média e alta

Durante a década de 1850, havia várias oportunidades para os membros respeitáveis das classes média e alta participarem de atividades ligadas ao 7 de Setembro. Anúncios para música de flauta e piano, incluindo variações sobre o hino da Independência, e uma "marcha triunfal para piano", junto com um retrato de Pedro I, são indicadores de celebrações domésticas. ${ }^{60} \mathrm{O}$ Hotel da França, localizado no Largo do Paço, oferecia pacotes especiais na sua varanda para "honradas famílias e sociedade" verem as "festas e magníficas iluminações" em segurança e conforto. ${ }^{61}$ Algumas das sociedades patrióticas da década de 1850 organizaram bailes, do mesmo modo que instituições privadas. $^{62}$

Uma série de artigos irônicos no Periódico dos Pobres permite entrever as atividades de uma família de classe média no 7 de Setembro no início da década de 1850. Morando no trajeto da parada, eram freqüentemente importunados por familiares que queriam vê-la das janelas e acabavam ficando para jantar. A parada dava azo a muito flerte, já que os balcóes das janelas viradas para as ruas eram "atopetados do belo sexo". "Tudo era galhofa, conversaçóes, em algumas a respeito deste, ou daquele que passava (...) algumas falando em modas, namoros, etc.” Os prédios no trajeto da parada eram, em 1851, "elegantemente ornados de ricas colchas e muito bonitas moças trajando com todo o primor”. Em 1850, um ano em que a parada foi arruinada pela chuva, "D. Mathias" compareceu ao cortejo, após o que ele e sua mulher jantaram com "um copinho de belo vinho fazendo uma saúde à Independência do Brasil". ${ }^{63}$

Essa noite, ele decidiu ir à gala do Teatro de São Pedro de Alcântara, mas, para seu grande desagrado, teve que pagar três mil-réis pelo bilhete ao invés dos dois mil-réis anunciados. A bilheteria não passava de uma "banca de peixe para ali regatear à vontade e escarnecer do público", uma queixa recorrente a respeito dos teatros da cidade. ${ }^{64}$ Não obstante, "D. Mathias” pagou esse valor ultrajante e juntou-se à família imperial, à maior parte da elite da cidade e a boa parte de sua classe média em um dos eventos mais tradicionais da sociabilidade do 7 de Setembro. Enquanto as 
mulheres da classe alta viam a gala teatral dos seus camarotes, a maioria da audiência era, como "D. Mathias", masculina e pagava o preço relativamente modesto dos lugares comuns na platéia, dos quais as mulheres estavam excluídas. ${ }^{65}$

Nos idos da década de 1810, o teatro emergira como lugar central da atividade política e, embora sua importância tenha em certa medida diminuído na década de 1820 , com a emergência do parlamento e de uma imprensa livre, a gala teatral permaneceu um importante barômetro do humor político. ${ }^{66}$ Todos os teatros da cidade montavam espetáculos de gala especiais nos feriados cívicos mais significativos, mas o que contava com a presença da família real era o de maior prestígio. O programa básico pouco mudou ao longo desses anos. À chegada dos monarcas ao seu camarote, a orquestra tocava o hino nacional ou o hino da Independência para acompanhar a prima-dona (ou toda a companhia da ópera) que entoava a letra. Ao que parece, o hino não era entoado coletivamente pelo público. Após, uma série de vivas envolvia toda a audiência; em 1850, unanimemente aclamaram a nação brasileira, a constituição, o monarca e a dinastia imperial. ${ }^{67}$ Os louvores podiam ser interrompidos por poetas que declamavam versos em honra do dia, tanto da platéia como dos camarotes. A peça central da noite era geralmente uma ópera ou drama europeus, mas podia ser antecedida ou seguida por uma pequena alegoria em honra do 7 de Setembro ou ainda por um entreato de dança.

Os louvores e as declamações de poemas eram, em certa medida, espontâneos. Com freqüência, os poetas distribuíam antecipadamente folhetos com os seus poemas, os quais depois apareciam na imprensa. Em 1850, “D. Mathias” ouviu o baboso soneto de Antônio José Nunes Garcia, que incluía os versos:

Se de PEDRO nos veio hoje a existência

Outorgando o Brasil melífluo favo

De nossas plagas exime o ser d'escravo

Dando-nos o renome, a Independência

...

O Filho de PEDRO herói!! PEDRO Segundo!!

Brasileiro Monarca! Egrégio, forte

De virtudes tantas, de saber profundo

Eternizará a Independência do Sul té o Norte. 
Garcia tropeçou nas palavras, "porém concluiu muito bem" ${ }^{68}$ Oito anos antes, Adalberto comentara que alguns dos cinco poetas "pareciam ter se desincumbido imperfeitamente de sua tarefa de decorar". ${ }^{69}$

Os espetáculos de ópera eram de qualidade variável. Em 1852, a Betly de Gaetano Donizetti "para nada prestou” e escapou por pouco de "uma tremenda pateada" da desapontada audiência (os espectadores se contiveram por respeito à família real), mas a Attila de Giuseppe Verdi teve mais sucesso no ano seguinte, bem como sua Il Trovatore em $1854 .^{70}$ A contenção da audiência em 1852, parte da tradição de não aplaudir espetáculos no 7 de Setembro, de modo a que as aclamações e os aplausos fossem reservados apenas à exaltação do próprio dia, desapareceu em 1855. Fãs das prima-donas, em aplausos ruidosos, pediam seu retorno ao palco após o espetáculo da Norma de Vincenzo Bellini. O gerente do Teatro Lírico permitiu que o fizessem e foi imediatamente preso pelo delegado de polícia, provocando uma enxurrada de cartas ao redator do Correio Mercantil. Em algumas dizia-se que houvera uma conspiração para que o gerente, nascido em Portugal, fosse aplaudido, o que representaria um insulto aos brasileiros. $^{71}$

No meio deste debate, o cronista do Correio Mercantil destacou que, na verdade, "a arte ainda não se nacionalizou". Naquele ano, todos os teatros da cidade tinham encenado produçóes estrangeiras para o 7 de Setembro e a maior parte dos componentes das companhias (incluindo as prima-donas) era estrangeira. Não era ridículo, perguntava, que atores estrangeiros cantassem o hino da Independência com os seus versos "Ou deixar a pátria livre/Ou morrer pelo Brasil"? Pior do que isso, o homem que cantou o verso "Brava gente brasileira" ria ao fazê-lo - o "maganão" sabia que, em italiano, a frase "brava gente" também podia significar "imbecis". ${ }^{72}$ Enrico Tamberlick, o tenor italiano que cantou o hino no ano seguinte, era de um patriotismo mais genuíno; a audiência irrompeu em aplausos quando ele pronunciou as palavras "pátria" e "Independência”, já que ele lutara pela independência italiana. ${ }^{73} \mathrm{~A}$ primeira ópera brasileira a ser encenada no 7 de Setembro no Rio de Janeiro foi $A$ Noite do Castelo, de Carlos Gomes, em 1861. ${ }^{74}$

Muito menos conhecidos do que estas óperas eram os ocasionais "elogios dramáticos” que buscavam expressar um ponto de vista político ou 
valores patrióticos. ${ }^{75}$ Em 1853, ao espetáculo de Attila no Teatro Provisório seguir-se-ia um novo "divertimento alegórico" ou "bailado alegórico", intitulado A glória do Brasil. Mostrava um homem representando o Brasil e cinco dançarinas nos papéis de Liberdade, Filosofia, Ignorância, Traição e Despotismo, junto com várias Fúrias e Ninfas. O enredo envolvia o Brasil sendo liberto das garras da Ignorância, da Traição e do Despotismo pela intervenção oportuna da Liberdade e da Filosofia, uma celebração transparente da concepção da elite do regime imperial. O cronista do Correio Mercantil escarneceu-o como uma "ridícula farçalhota", na qual o Brasil era representado por "um figurão vestido de trapos com algemas de folha de Flandres nas mãos e um farrapo na cabeça”. A "menina loureira" que desempenhava o papel da Filosofia parecia-se com uma dessas mulheres que conseguiam empobrecer muitos homens brasileiros quando dançava em volta do Brasil "com as gâmbias à mostra, deixando ver um pezinho delicado" ${ }^{76}$

Apenas uma vez durante as décadas de 1840 e 1850 o teatro de gala incluiu uma peça diretamente baseada em eventos históricos. Em 1840, o Teatro de São Pedro de Alcântara apresentou $A$ expulsão dos holandezes ou $O$ heroismo brasileiro de G. J. de M. Pimentel. A única descrição disponível do espetáculo é de um crítico cujo relato sugere que a peça apresentava uma interpretação questionadora das hierarquias sociais brasileiras. Ele não gostou do papel proeminente dado a Henrique Dias, o herói negro destas guerras do século XVII em Pernambuco, pois ele era um africano e não um brasileiro e porque "pareceram um pouco subversivas algumas palavras que no princípio disse em favor dos pretos". Além disso, a peça mostrava os índios como incorrompidos até a chegada dos europeus. $\mathrm{O}$ crítico declarava que os brasileiros não eram negros nem índios e agradecia a Deus pelo "sangue europeu" que corria em suas veias. Declarações de que a terra pertencia aos índios equivaliam a convidar os chefes botocudos a assumir controle do Rio de Janeiro. Isto tudo, concluía o crítico, era um insulto à família real, "cuja grandeza e majestade todo provem do sangue europeu, ilustre e antiguíssimo". ${ }^{77}$ De modo mais explícito do que praticamente qualquer outra pessoa, o crítico mostrava a visão da sociedade brasileira representada no teatro de gala. É bem verdade que as regras de comportamento da elite sobre raça implicavam que tais assertivas explícitas sobre identidade racial praticamente não encontrassem expressão pública na im- 
prensa; todavia a identidade racial estava latente em boa parte da comemoração do 7 de Setembro. ${ }^{78}$

O teatro cumpria, pois, várias funções. Oferecia uma ocasião aos membros da elite de serem vistos em público e em associação com o imperador. Como conjunto, participava da alta cultura européia e expressavam suas lealdades políticas. As alegorias canhestras e a poesia pretensiosa refletiam a concepção de que o teatro era uma instituição didática cuja tarefa era incrementar a cultura e a civilização das pessoas. No mesmo sentido em que este projeto, associado de perto com o realismo, em última análise falhou, o efeito didático das alegorias era provavelmente bastante limitado sobre as platéias teatrais sofisticadas da capital. ${ }^{79}$

Escrevendo no final da década de 1880, o folclorista Alexandre José de Melo Moraes Filho declarou que, cerca de trinta anos antes, "as festas do aniversário da Independência (...) eram estrondosas e possuíam o relevo das consagraçôes populares”. Todavia a Guerra do Paraguai (1864-70), "a liquidação final do patriotismo brasileiro", deu início a um declínio na cultura patriótica e apenas o silêncio permaneceu. ${ }^{80}$ Embora sem dúvida Melo Moraes tenha visto muitas mudanças ao longo de sua vida, o que ele descrevia como celebrações típicas do 7 de Setembro eram, na verdade, as comemoraçôes próprias do final da década de 1850, e seu declínio provinha de antes da guerra.

Oficialmente, as comemoraçôes do 7 de Setembro das décadas de 1840 e 1850 apresentavam uma concepção sobre a identidade nacional brasileira que destacava a excelência das instituições monárquico-constitucionais outorgadas por Pedro I, garantidas por Pedro II e endossadas por sua população ordeira. Permanece difícil discernir o que africanos, escravos e classes inferiores que lutavam para conseguir sobreviver na cidade pensavam sobre as celebraçóes (que não podiam ter deixado de acompanhar). Pode-se apenas especular sobre os incômodos sofridos pelas quitandeiras despejadas em 1858 (e sobre se teriam se beneficiado com vendas às multidões que afluíam à noite). Do mesmo modo, tudo o que se pode fazer é especular sobre os motivos por trás dos que vandalizaram a fonte temporária. Alguns historiadores defendem que havia uma influência recíproca entre os festivais populares e os rituais cívicos, sobretudo em termos de interpretação da monarquia. ${ }^{81}$ Embora atraente, é difícil demons- 
trar esta leitura a partir das celebraçōes do 7 de Setembro, que claramente diferiam dos festivais populares. Não obstante, o rápido declínio das comemorações do 7 de Setembro no início da década de 1860 bem pode apontar para os limites deste apelo nacionalista.

\section{Notas}

${ }^{1}$ A pesquisa para este artigo contou com o apoio do Social Sciences and Humanities Research Council (Canada) - Conselho de Pesquisa em Ciências Sociais e Humanas (Canadá), da University Research Grants Committee (University of Calgary) - Comissão de Bolsas de Pesquisa da Universidade (Universidade de Calgary), com uma Killam Resident Fellowship (University of Calgary) - Bolsa Killam de Professor Residente (Universidade de Calgary) e com uma bolsa de Professor Visitante Estrangeiro da Coordenação de Aperfeiçoamento de Pessoal de Nível Superior (CAPES). Sonya Marie Scott auxiliou na pesquisa em 1999-2000. Agradeço a José Murilo de Carvalho por seus comentários a uma versão anterior, que também foi apresentada na Conference on Latin American History - Congresso sobre História Latino-Americana, Washington, janeiro de 2004; e nos departamentos de história da Pontifícia Universidade Católica do Rio de Janeiro (outubro de 2004) e da Universidade Federal de Minas Gerais, Belo Horizonte (novembro de 2004). Nas notas foram utilizadas as seguintes abreviaçôes: AGCRJ (Arquivo Geral da Cidade do Rio de Janeiro); BNRJ (Biblioteca Nacional, Rio de Janeiro). Todos os jornais citados foram publicados no Rio de Janeiro. A tradução do presente artigo para o português foi realizada por Irene Portela.

${ }^{2}$ Correio Mercantil, 7 de setembro de 1854.

${ }^{3}$ Relatório dos trabalhos da directoria provisoria (...), 30 de agosto de 1855 - 30 de setembro de 1856, Correio Mercantil, 23 de março de 1857.

${ }^{4}$ Sessōes de 5 e 9 de setembro de 1823, BRASIL. Diário da Assembléa Geral Constituinte e Legislativa do Império do Brasil, 1823. Ed. facsimilar. Brasília: Senado Federal, 1972, v. 1, pp. 722, 733; Lei, 9 de setembro de 1826, Coleção das Leis do Império do Brasil. Ver também NEVES, Lúcia Maria Bastos Pereira das. Corcundas e constitucionais: a cultura politica da Independência (1820-1822). Rio de Janeiro: Faperj e Revan, 2003, pp. 369-370.

${ }^{5}$ LYRA, Maria de Lourdes Viana. Memória da Independência: marcos e representaçōes simbólicas. Revista Brasileira de História v. 15, n. 29, pp. 173-206, 1995; KRAAY, Hendrik. Nação, Estado e politica popular no Rio de Janeiro: rituais cívicos depois da Independência. In: DOYLE, Don, e PAMPLONA, Marco (Orgs.). Nacionalismo no Novo Mundo. Rio de Janeiro: Record, no prelo.

${ }^{6}$ WILENTZ, Sean (Org.). Rites of Power: Symbolism, Ritual, and Politics since the Middle Ages. Philadelphia: University of Pennsylvania Press, 1999; GILLIS, John R. (Org.). Commemorations: The Politics of National Identity. Princeton: Princeton University Press, 1994; KERTZER, David I. Ritual, Politics, and Power. New Haven: Yale University Press, 1988. 
${ }^{7}$ BEEZLEY, William H., e LOREY, David E. (Orgs.). 'Viva Mexico!!Viva La Independencia! Celebrations of September 16. Wilmington: Scholarly Resources, 2001; EARLE, Rebecca. 'Padres de la Patria' and the Ancestral Past: Commemorations of Independence in Nineteenth-Century Spanish America. Journal of Latin American Studies, v. 34, n. 4, pp. 775-806, 2002.

${ }^{8}$ LOMNITZ-ADLER, Claudio. Exits from the Labyrinth: Culture and Ideology in the Mexican National Space. Berkeley: University of California Press, 1992, p. 6. Sobre essa questão, ver também CARDOSO, Ângela Miranda. Ritual: princípio, meio e fim. Do sentido do estudo das cerimônias de entronização brasileiras. In: JANCSÓ, István (Org.). Brasil: formação do Estado e da nação. São Paulo: Hucitec, Ed. Unijuí e Fapesp, 2003, pp. 549-602.

${ }^{9}$ KARASCH, Mary C. Slave Life in Rio de Janeiro, 1808-1850. Princeton: Princeton University Press, 1987, p. 66.

${ }^{10}$ Sobre a história política dessa época, ver os capítulos relevantes de BARMAN, Roderick J. Brazil: The Forging of a Nation, 1798-1852. Stanford: Stanford University Press, 1988; BARMAN, Roderick J. Citizen Emperor: Pedro II and the Making of Brazil, 1825-1891 Stanford: Stanford University Press, 1999.

${ }^{11}$ ADALBERT. Travels of His Royal Highness Prince Adalbert of Prussia. London: David Bogue, 1849, v. 1, pp. 270-279. Ver também Jornal do Commercio, 8-9 de setembro de 1842.

${ }^{12}$ Sobre rituais coloniais, ver JANCSÓ, István e KANTOR, Iris (Orgs.). Festa: cultura e sociabilidade na América portuguesa. São Paulo: Edusp, 2001; sobre a continuidade entre rituais coloniais e os do Primeiro Reinado, ver SOUZA, Iara Lis Carvalho. Pátria coroada: o Brasil como corpo político autônomo, 1780-1831. São Paulo: Editora da Unesp, 1998.

${ }^{13}$ ANDERSON, Benedict. Imagined Communities: Reflections on the Origin and Spread of Nationalism. London: Verso, 1991.

${ }^{14}$ O Americano, 8 de setembro de 1849. Ver também Correio do Brazil, 7 de setembro de 1852; O Pavilhão Nacional, 7 de setembro de 1850.

${ }^{15} O$ Social, 9 de setembro de 1845 . Ver também $O$ Tempo, 10 de setembro de 1846.

${ }^{16}$ O Brado do Amazonas, 7 de setembro de 1854 . Ver também O Brasil, 10 de setembro de 1850 .

${ }^{17}$ RIBEIRO, Maria Eurydice de Barros. Memória em bronze: estátua eqüestre de D. Pedro I. In: KNAUSS, Paulo (Org.). Cidade vaidosa: imagens urbanas do Rio de Janeiro. Rio de Janeiro: Sette Letras, 1999, pp. 15-28; GREEN, James N. The Emperor on His Pedestal: Pedro I and Disputed Views of the Brazilian Nation, 1860-1900. In: NAVA, Carmen, e LAUERHASS, Ludwig (Orgs.). Brazil in the Making: Facets of National Identity. Lanham: Rowman and Littlefield, 2006, pp. 181-202.

${ }^{18}$ O Mercantil, 8 de setembro de 1845 .

${ }^{19}$ Ao amigo ausente, Jornal do Commercio, 7 de setembro de 1851. Ver também Correio da Tarde, 9 de setembro de 1851.

${ }^{20}$ O Echo do Rio, 9 de setembro de 1843; O Mercantil, 7 de setembro de 1847. 
${ }^{21} O$ Mercantil, 8 de setembro de 1845 .

${ }^{22}$ RIBEIRO, Gladys Sabino. A liberdade em construção: identidade nacional e conflitos antilusitanos no Primeiro Reinado. Rio de Janeiro: Relume-Dumará, 2002; MOSHER, Jeffrey C. Political Mobilization, Party Ideology, and Lusophobia in Nineteenth-Century Brazil: Pernambuco, 1822-1850. Hispanic American Historical Review, v. 80, n. 4, pp. 881-912, 2000; KRAAY, no prelo.

${ }^{23}$ Correio da Tarde, 9 de setembro de 1848; Jornal do Commercio, 11 de setembro de 1848; Correio Mercantil, 9 e 12 de setembro de 1848; O Farricoco, 10 de novembro de 1848.

${ }^{24} O$ Velho Brasil, 14 de setembro de 1854.

${ }^{25}$ O Repúblico, 18 de setembro de 1854. Sobre as comemoraçōes do Dois de Julho em Salvador, ver KRAAY, Hendrik. Between Brazil and Bahia: Celebrating Dois de Julho in Nineteenth-Century Salvador. Journal of Latin American Studies, v. 32, n. 2, pp. 255286, 1999.

${ }^{26}$ Ver os anúncios no Jornal do Commercio, 7 de setembro de 1855, 7 de setembro de 1856, 6 de setembro de 1857.

${ }^{27}$ Programa dos festejos que a Sociedade "Ypiranga" tem deliberado fazer (...), [1856], AGCRJ, 43-3-64, fol. 3r-v; Programa dos festejos que a Sociedade Ypiranga pertende [sic] fazer no dia 7 de Setembro de 1857, BNRJ/SM, II-31, 33, 19; Correio da Tarde, 9 de setembro de 1856.

${ }^{28}$ Sociedade Independência Brasileira para Câmara Municipal, Rio de Janeiro, 29 de julho de 1857, 31 de julho de 1858, AGCRJ, 43-3-64, fols. 6, 10; Chronica da semana e Chronica da quinzena, $1^{\circ}$ e 20 de setembro de 1859, Revista Popular, v. 1, n. 3, pp. 333, 396, 1859.

${ }^{29}$ Folhetim, Jornal do Commercio, 9 de setembro de 1855; A Semana, 28 de setembro de 1856; Jornal do Commercio, 9 de setembro de 1856; Folhetim, Jornal do Commercio, 14 de setembro de 1856; Páginas Menores, Correio Mercantil, 7 de setembro de 1856.

${ }^{30}$ Folhetim, Jornal do Commercio, 14 de setembro de 1857 . Ver também Jornal do Commercio, 8-9 de setembro de 1857.

${ }^{31}$ Folhetim, Jornal do Commercio, 13 de setembro de 1858.

32 Chronica da quinzena, 20 de setembro de 1859, Revista Popular, v. 1, n. 3, pp. 394395; Correio Mercantil, 8-9 de setembro de 1859; Jornal do Commercio, 8-9 de setembro de 1859; Correio da Tarde, 9 de setembro de 1859.

${ }^{33}$ Ver os requerimentos em AGCRJ, 43-3-64, fols. 11, 15, 16, 20; Correio da Tarde, 15 de julho de 1858, 5 de setembro de 1859; Correio Mercantil, 5 e 6 de setembro de 1859. ${ }^{34}$ Correspondência de O Oprimido, O Tyranno, 12 de setembro de 1857.

35 Páginas Menores, Correio Mercantil, 14 de setembro de 1857; A Marmota, 14 de setembro de 1858; $O$ Charivary Nacional, 4 de setembro de 1859.

36 D. C., Saudação ao dia 7 de setembro, Correio Mercantil, 7 de setembro de 1859; Folhetim, Jornal do Commercio, 7 de setembro de 1856. 
${ }^{37}$ O Tyranno, 12 de setembro de 1857; O Carapuça, 6 de setembro de 1857; 7 de Setembro, 7 de setembro de 1859; O Clamor Publico, 7 de setembro de 1860; A Crença, 6 de setembro de 1863 .

${ }^{38}$ Folhetim, Jornal do Commercio, 8-9 de setembro de 1860.

${ }^{39}$ Chronica da quinzena, 10 de setembro de 1860 [sic = 1861], Revista Popular v. 3, n.:11, p.(1861): 377, 1861. Ver também A Marmota, 6 de setembro de 1861 .

${ }^{40}$ O Espectador da América do Sul, 10 de setembro de 1863; Jornal do Commercio, 3 de setembro de 1863. Ver também $O$ Constitucional, 7 de setembro de 1863.

${ }^{41}$ Jornal do Commercio, 10 de setembro de 1856; Correio Mercantil, 8-9 de setembro de 1858; Relatório dos trabalhos.

${ }^{42}$ Correio da Tarde, 6 de setembro de 1858.

${ }^{43}$ Esta análise do significado da rua é baseada na interpretação sobre "casa" e "rua" na cultura brasileira de Roberto Da Matta. DA MATTA, Roberto. A casa e a rua: espaço, cidadania, mulher e morte no Brasil. São Paulo: Brasiliense, 1985.

44 Jornal do Commercio, 5 de setembro de 1858; Correio da Tarde, 9 de setembro de 1858.

${ }^{45}$ Correio Mercantil, 5 de setembro de 1858.

${ }^{46}$ Jornal do Commercio, 12 de setembro de 1858, 7 de setembro de 1859, 7 de setembro de 1860, 7 de setembro de 1861 .

${ }^{47}$ Correspondência de $\mathrm{O}$ cego que vê, o surdo que ouve, Jornal do Commercio, 2 de setembro de 1856. Sobre os planos para as fogueiras, ver Correio Mercantil, 6 de setembro de 1856; Páginas menores, Correio Mercantil, 7 de setembro de 1856.

48 Jornal do Commercio, 9 de setembro de 1845; Correio Mercantil, 10 de setembro de 1857; Correio da Tarde, 9 e 10 de setembro de 1859. Sobre a presença de capoeiras em festividades públicas, ver SOARES, Carlos Eugênio Líbano. A negregada institutição: os capoeiras na corte imperial, 1850-1890. Rio de Janeiro: Access, 1999, pp. 79-83; HOLLOWAY, Thomas H. A Healthy Terror: Police Repression of 'Capoeiras' in Nineteenth-Century Rio de Janeiro. Hispanic American Historical Review, v. 69, n. 4, 1989, pp. 665, 670; CHVAICER, Maya Talmon. The Criminalization of 'Capoeira' in Nineteenth-Century Rio de Janeiro. Hispanic American Historical Review, v. 82, n. 3, pp. 531-532, 2002; ASSUNÇÃO, Matthias Röhrig. Capoeira: The History of an Afro-Brazilian Martial Art. London: Routledge, 2005, pp. 80-83.

49 A Semana, 28 de setembro de 1856.

50 Correio Mercantil, 8-9 de setembro de 1857.

${ }^{51}$ Há dois relatos diferentes sobre este episódio: Jornal do Commercio, 11 de setembro de 1859; Correio Mercantil, 11 de setembro de 1859. A condenação da polícia foi publicada em 7 de Setembro, 18 de setembro de 1859.

52 BETHELL, Leslie. The Abolition of the Brazilian Slave Trade: Britain, Brazil, and the Slave Trade Question. Cambridge: Cambridge University Press, 1970, p. 313; CONRAD, Robert. The Destruction of Brazilian Slavery, 1850-1888. Berkeley: University of California Press, 1972, p. 27. 
53 Correio da Tarde, $1^{\circ}$ e 5 de setembro de 1856.

${ }^{54}$ KARASCH, 1987, p. 345.

${ }^{55}$ Jornal do Commercio, 7 e 9 de setembro de 1856; Relatório dos trabalhos; Carta de João Fernandes a seu compadre Manoel Mendes, Correio da Tarde, 6 de setembro de 1856.

56 Páginas menores, Correio Mercantil, 7 e 21 de setembro de 1856.

${ }^{57}$ Folhetim, Jornal do Commercio, 14 de setembro de 1857; Correio da Tarde, 15 de julho de 1857; Correio Mercantil, 12 de setembro de 1857.

${ }^{58}$ Correio Mercantil, 8-9 de setembro de 1857.

59 A Marmota, 14 de setembro de 1858; O Constitucional, 10 de setembro de 1862.

${ }^{60}$ Jornal do Commercio, 5 de setembro de 1857; Correio Mercantil, 6 de setembro de 1856. Sobre pianos na sociedade fluminense, ver MAGALDI, Cristina. Music in Imperial Rio de Janeiro: European Culture in a Tropical Milieu. Lanham: Scarecrow Press, 2004, pp. 8-12.

${ }^{61}$ Jornal do Commercio, 4 de setembro de 1856.

62 Jornal do Commercio, 5 de setembro de 1851; 6 de setembro de 1856; 7 de setembro de 1856; 6 de setembro de 1864; Correio Mercantil, 8-9 de setembro de 1859.

${ }^{63}$ Carta de D. Mathias ao seu compadre Pitorra, Periodico dos Pobres, 7 de setembro de 1850; Visita das priminhas, Periodico dos Pobres, 9 de setembro de 1854; 9 de setembro de 1851.

${ }^{64}$ Carta de D. Mathias (...), Periodico dos Pobres, 10 de setembro de 1850; A directoria do Theatro Lyrico e a polícia, Correio Mercantil, 8 de setembro de 1855; Theatro Lyrico, Correio da Tarde, 10 de setembro de 1855.

${ }^{65}$ GIRON, Luís Antônio. Minoridade crítica: a ópera e o teatro nos folhetins da Corte. São Paulo: Editora da Universidade de São Paulo / Rio de Janeiro: Ediouro, 2004, p. 98. As evidências sobre a composição social das platéias teatrais é escassa e contraditória. Embora Silvia Cristina Martins de Souza observe que os preços dos bilhetes eram suficientemente baixos para que os artesãos mais qualificados pudessem ir aos espetáculos teatrais, ela não sugere que tais membros das classes operárias o fizessem. Caixeiros e estudantes eram, todavia, espectadores assíduos. SOUZA, Cristina Martins de. As noites do Ginásio: teatro e tensóes culturais na Corte (1832-1868). Campinas: Editora da Unicamp, 2002, pp. 128 (nota 68), 279-282. Cristina Magaldi oscila entre destacar a natureza socialmente exclusiva das platéias teatrais e seu alcance social. MAGALDI, 2004, pp. xxi, 13, 17, 31 (nota 45), 38-39, 54, 60 (notas 13-14).

${ }^{66}$ Sobre essas mudanças, ver MOREL, Marco. As transformaçōes dos espaços públicos: Imprensa, atores políticos e sociabilidades na cidade imperial. São Paulo: Hucitec, 2005. Sobre o teatro como espaço político, ver também MALERBA, Jurandir. A corte no exílio: civilização e poder no Brasil às vésperas da Independência (1808 a 1821). São Paulo: Companhia das Letras, 2000, pp. 91-124; MAMMI, Lorenzo. Teatro em música no Brasil monárquico. In: JANCSÓ e KANTOR, 2001, v. 1, pp. 48-49; MAGALDI, 2004, pp. 12-13.

${ }^{67} \mathrm{O}$ Brasil, 10 de setembro de 1850.

${ }^{68}$ Carta de D. Mathias (...) e Soneto recitado no theatro na noite de Sete de Setembro, Periodico dos Pobres, 10 de setembro de 1850.

TOPOI, v. 8, n. 14, jan.-jun. 2007, pp. 9-36. 
${ }^{69}$ ADALBERT, 1849 , v. 1, p. 279.

${ }^{70}$ Visita das priminhas, Periodico dos Pobres, 9 de setembro de 1852; Folhetim, Jornal do Commercio, 11 de setembro de 1853; Jornal do Commercio, 10 de setembro de 1854.

${ }^{71}$ Carta de João Fernandes (...), Correio da Tarde, 10 de setembro de 1855; Correspondências, Correio Mercantil, 8, 10 e 11 de setembro de 1855. Sobre os "partidos" ou "façõos teatrais" e a sua repressão pela polícia, ver GIRON, 2004, pp. 14, 73-75, 82-83, 89, 97-99, 134, 147; S. SOUZA, 2002, pp. 58-59, 289-291; MAGALDI, 2004, p. 47. 72 Páginas menores, Correio Mercantil, 8 de setembro de 1855 . Sobre a campanha para uma ópera nacional, ver GIRON, 2004, pp. 158-163, 190-197.

${ }^{73}$ Correio Mercantil, 8-9 de setembro de 1856; Páginas menores, Correio Mercantil, 21 de setembro de 1856.

${ }^{74}$ Jornal do Commercio, 4 de setembro de 1861; Correio da Tarde, 8 de setembro de 1861. Sobre esta ópera, ver GIRON, 2004, pp. 197-201.

75 Sobre tais elogios, ver MALERBA, 2000, pp. 100-111; MAMMI, 2001, pp. 46-47.

${ }^{76} 137^{a}$ pacotilha, Carijó e Comp ${ }^{\underline{a}}$, Correio Mercantil, 11 de setembro de 1853.

77 Correspondência de Hum Irmão da Caridade, Jornal do Commercio, 10 de setembro de 1840.

${ }^{78}$ Sobre a etiqueta racial imperial, ver COSTA, Emília Viotti da. The Brazilian Empire: Myths and Histories. Chapel Hill: University of North Carolina Press, 2000, pp. 241-244.

${ }^{79}$ Sobre a missão civilizadora do teatro, ver S. SOUZA, 2002.

${ }^{80}$ MELLO MORAES FILHO, [Alexandre José de]. Festas e tradiçôes populares do Brasil. 3르. Ed., Rio de Janeiro: F. Briguiet \& Cia., 1946, pp. 147, 152. Este artigo foi originalmente publicado na Gazeta de Notícias, 7 de setembro de 1887.

${ }^{81}$ SCHWARCZ, Lilia Moritz. As barbas do imperador: D. Pedro II, um monarca nos trópicos. 2a Ed., São Paulo: Companhia das Letras, 1999, pp. 257-259; ABREU, Martha. O império do Divino: festas religiosas e cultura popular no Rio de Janeiro, 1830-1900. Rio de Janeiro: Nova Fronteira, 1999.

\section{Referências bibliográficas}

ABREU, Martha. O império do Divino: festas religiosas e cultura popular no Rio de Janeiro, 1830-1900. Rio de Janeiro: Nova Fronteira, 1999.

ADALBERT. Travels of His Royal Highness Prince Adalbert of Prussia. London: David Bogue, 1849.

ANDERSON, Benedict. Imagined Communities: Reflections on the Origin and Spread of Nationalism. London: Verso, 1991.

ASSUNÇÃO, Matthias Röhring. Capoeira: The History of an Afro-Brazilian Martial Art. London: Routledge, 2005. 
BARMAN, Roderick J. Brazil: The Forging of a Nation, 1798-1852. Stanford: Stanford University Press, 1988. . Citizen Emperor: Pedro II and the Making of Brazil, 1825-1891. Stanford: Stanford University Press, 1999.

BEEZLEY, William H., e LOREY, David E. (Orgs.). 'Viva Mexico! !Viva La Independencia! Celebrations of September 16. Wilmington: Scholarly Resources, 2001.

BETHELL, Leslie. The Abolition of the Brazilian Slave Trade: Britain, Brazil, and the Slave Trade Question. Cambridge: Cambridge University Press, 1970.

BRASIL. Diário da Assembléa Geral Constituinte e Legislativa do Império do Brasil, 1823. Ed. Facsimilar. Brasília: Senado Federal, 1972.

CARDOSO, Ângela Miranda. Ritual: princípio, meio e fim. Do sentido do estudo das cerimônias de entronização brasileiras. In: JANCSÓ, István (Org.). Brasil: formaçãa do Estado e da nação. São Paulo: Hucitec, Ed. Unijuí e Fapesp, 2003. pp. 549-602.

CHVAICER, Maya Talmon. The Criminalization of Capoeira in NineteenthCentury Rio de Janeiro. Hispanic American Historical Review, v. 82, n. 3, pp. 525-547, 2002.

CONRAD, Robert. The Destruction of Brazilian Slavery, 1850-1888. Berkeley: University of California Press, 1972.

COSTA, Emília Viotti da. The Brazilian Empire: Myths and Histories. Chapel Hill: University of North Carolina Press, 2000.

DA MATTA, Roberto. A casa e a rua: espaço, cidadania, mulher e morte no Brasil. São Paulo: Brasiliense, 1985.

EARLE, Rebecca. 'Padres de la Patria' and the Ancestral Past: Commemorations of Independence in Nineteenth-Century Spanish America. Journal of Latin American Studies, v. 34, n. 4, pp. 775-806, 2002.

GILLIS, John R. (Org.). Commemorations: The Politics of National Identity. Princeton: Princeton University Press, 1994.

GIRON, Luís Antônio. Minoridade crítica: a ópera e o teatro nos folhetins da Corte. São Paulo: Editora da Universidade de São Paulo; Rio de Janeiro: Ediouro, 2004.

GREEN, James N. The Emperor on His Pedestal: Pedro I and Disputed Views of the Brazilian Nation, 1860-1900. In: NAVA, Carmen, e LAUERHASS JR., Ludwig (Orgs.). Brazil in the Making: Facets of National Identity. Lanham: Rowman and Littlefield, 2006. pp. 181-202.

HOLLOWAY, Thomas H. 'A Healthy Terror': Police Repression of Capoeiras in Nineteenth-Century Rio de Janeiro. Hispanic American Historical Review, v. 69, n. 4, pp 673-676, 1989. 
JANCSÓ, István e KANTOR, Iris (Orgs.). Festa: cultura e sociabilidade na América portuguesa. São Paulo: EDUSP, 2001.

KARASCH, Mary C. Slave Life in Rio de Janeiro, 1808-1850. Princeton: Princeton University Press, 1987.

KERTZER, David I. Ritual, Politics, and Power. New Haven: Yale University Press, 1988.

KRAAY, Hendrik. Between Brazil and Bahia: Celebrating Dois de Julho in Nineteenth-Century Salvador. Journal of Latin American Studies, v. 32, n. 2, pp. 255-286, 1999.

KRAAY, Hendrik. Nação, Estado e política popular no Rio de Janeiro: rituais cívicos depois da Independência. In: DOYLE, Don, e PAMPLONA, Marco (Orgs.). Nacionalismo no Novo Mundo. Rio de Janeiro: Record, no prelo.

LOMNITZ-ADLER, Claudio. Exits from the Labyrinth: Culture and Ideology in the Mexican National Space. Berkeley: University of California Press, 1992.

LYRA, Maria de Lourdes Viana. Memória da Independência: marcos e representações simbólicas. Revista Brasileira de História, v. 15, n. 29, pp. 173-206, 1995.

MAGALDI, Cristina. Music in Imperial Rio de Janeiro: European Culture in a Tropical Milieu. Lanham: Scarecrow Press, 2004.

MALERBA, Jurandir. A corte no exílio: civilização e poder no Brasil às vésperas da Independência (1808 a 1821). São Paulo: Companhia das Letras, 2000.

MAMMI, Lorenzo. Teatro em música no Brasil monárquico. In: JANCSÓ, István, e KANTOR, Iris (Orgs.). Festa: cultura e sociabilidade na América portuguesa. São Paulo: Edusp, 2001. v. 1, pp. 37-52.

MELLO MORAES FILHO, [Alexandre José de]. Festas e tradiçôes populares do Brasil. 3를. Ed. Rio de Janeiro: F. Briguiet \& Cia., 1946.

MOREL, Marco. As transformaçōes dos espaços públicos: imprensa, atores políticos e sociabilidades na cidade imperial. São Paulo: Hucitec, 2005.

MOSHER, Jeffrey C. Political Mobilization, Party Ideology, and Lusophobia in Nineteenth-Century Brazil: Pernambuco, 1822-1850. Hispanic American Historical Review, v. 80, n. 4, pp. 881-912, 2000.

NEVES, Lúcia Maria Bastos Pereira das. Corcundas e constitucionais: a cultura politica da Independência (1820-1822). Rio de Janeiro: Faperj e Revan, 2003.

RIBEIRO, Gladys Sabino. A liberdade em construção: identidade nacional e conflitos antilusitanos no Primeiro Reinado. Rio de Janeiro: Relume-Dumará, 2002.

RIBEIRO, Maria Eurydice de Barros. Memória em bronze: estátua eqüestre de D. Pedro I. In: KNAUSS, Paulo (Org.). Cidade vaidosa: imagens urbanas do Rio de Janeiro. Rio de Janeiro: Sette Letras, 1999. pp. 15-28. 
SCHWARCZ, Lilia Moritz. As barbas do imperador: D. Pedro II, um monarca nos trópicos. $2^{\mathrm{a}}$ Ed. São Paulo: Companhia das Letras, 1999.

SOARES, Carlos Eugênio Líbano. A negregada instituição: os capoeiras na corte imperial, 1850-1890. Rio de Janeiro: Access, 1999.

SOUZA, Iara Lis Carvalho. Pátria coroada: o Brasil como corpo político autônomo, 1780-1831. São Paulo: Editora da Unesp, 1998.

SOUZA, Silvia Cristina Martins de. As noites do Ginásio: teatro e tensões culturais na Corte (1832-1868). Campinas: Editora da Unicamp, 2002.

WILENTZ, Sean (Org.). Rites of Power: Symbolism, Ritual, and Politics since the Middle Ages. Philadelphia: University of Pennsylvania Press, 1999.

\section{RESUMO}

Neste artigo examinam-se as celebraçôes da Independência brasileira no Rio de Janeiro do início da década de 1840 a meados da década de 1860. Analisa-se o surto de comemoraçôes populares na década de 1850 e reflete-se sobre a imagem da nação brasileira manifesta publicamente nas ruas da capital. Havia uma identificação significativa, apesar de socialmente circunscrita, com o estado-nação brasileiro entre a população urbana.

Palavras-chave: Rituais cívicos, Rio de Janeiro, cultura política, celebraçôes da Independência brasileira, Império brasileiro.

\section{ABSTRACT}

This article examines the celebrations of Brazilian independence in Rio de Janeiro from the early 1840s to the mid-1860s. It analyzes the surge of popular commemorations in the 1850s and examines the image of the Brazilian nation publicly manifested on the capital's streets. There was a significant, albeit socially circumscribed, identification with the Brazilian nation-state among the urban population.

Keywords: Civic Rituals, Rio de Janeiro, Political Culture, Brazilian Independence Celebrations, Brazilian Empire.

(recebido em agosto de 2006 e aprovado em novembro do mesmo ano) 